\title{
Design and Simulation of Wind Pump System for Ban Village
}

\author{
Maren I. Borok ${ }^{1 *} \quad$ Zwalnan, S. Johnson ${ }^{2} \quad$ Sanda Sayyadi $^{3}$ \\ 1.Department of Mechanical Engineering, Plateau State Polytechnic, Barkin-Ladi, P.M.B. 02023, Bukuru, Jos, \\ Nigeria \\ 2.Department of Metallurgy and Foundry Technology Engineering, Plateau State Polytechnic, Barkin-Ladi, \\ P.M.B. 02023, Bukuru, Jos, Nigeria \\ 3.Post-graduate student, Department of Mechanical Engineering, Ahmadu Bello University, Zaria, Nigeria \\ ${ }^{*}$ Corresponding author: borokishaku@gmail.com
}

\begin{abstract}
The significance of water to human existence can never be overemphasized. Most rural areas do not have access to portable drinking water. Underground water has been adjudged by World Health Organization (WHO) to be a relatively better alternative source of portable drinking water. Hand pump may not provide adequate water for larger community; diesel engine pump emits Green House Gases (GHG). Thus a relatively better alternative source of energy is the wind. Wind pump is designed for Ban village to pump water from borehole to an overhead tank to be supplied to the village, since Ban village is considered to be one of the locations in Nigeria that has high wind speed that can be harnessed for wind pump technology. Design results show that a $3.6 \mathrm{~m}$ diameter wind mill will be required to pump water from borehole through a total head of $35 \mathrm{~m}$ to the village to meet the daily water need of $25 \mathrm{~m}^{3}$. Results from the Wind Energy Resources Analysis (WERA) software simulation using the wind speed characteristics of the region shows that the monthly water discharge by wind pump is proportional to the monthly average wind speed with the peak monthly discharge of about $3000 \mathrm{~m}^{3}$ in January which declines to about $1,000 \mathrm{~m}^{3}$ in October. This volume of water is enough to meet the monthly water need of the village.
\end{abstract}

Keywords: Wind speed, Wind pump, Simulation,

\subsection{Introduction}

Water is indispensible for the existence of man, animals and plants on earth. The total amount of water in a man of average weight (70 kilogrammes) is approximately 40 litres, averaging 57 percent of his total body weight and the human body is about $60 \%$ water in adult males and $70 \%$ in adult females (Guyton, 1991).

From the very beginning of human civilisation, people have settled close to water sources along rivers, ponds, besides lakes or natural springs. However, as population increases such sources of water become polluted due to human activities and are no longer fit for direct consumption. Report has shown that, water-related diseases are among the most common causes of illness and death, affecting mainly the poor in developing countries. They kill more than 5 million people every year, more than ten times the number killed in wars. The diseases can be divided into four categories: water-borne, water-based, water-related, and water-scarce diseases (UNESCO, 2011).

In developing countries, potable drinking water has remained a serious problem especially to those living in the rural areas because most rural areas are far from metropolitan water treatment plants thus the distribution of treated water to such areas is highly expensive. At the same time, rainfall is decreasing in many tropical countries due to climatic changes, so surface water is becoming scarce. Groundwater seems to be the only alternative to this dilemma, but the groundwater table is also decreasing, which makes traditional hand pumping and bucketing from shallow wells difficult (Argaw et al, 2001). Thus, mechanised or motorised water pumping will become the only reliable alternative for lifting water from underground.

However, there are challenges in using motorised water pump due to the poor energy situation in Nigeria. Most rural areas are not connected to the national grid and the few that are connected do not have effective and efficient power supply thereby making it difficult to use motorised water pump. Diesel and kerosene pumps load the atmosphere with greenhouse gases (GHG) and particulates, resulting in global warming and climate change.

Renewable energy technologies such as wind, is better options in remote locations especially in Nigeria in the face of the current energy crisis. Nigeria is endowed with enormous wind energy potential. Wind pumps are now emerging in the market and are rapidly becoming more attractive as alternative sources of energy for pumping water. Even though wind energy is stochastic, the incorporation of storage tank will supply water when the wind energy is not available or enough to pump water.

Ban is a small village in Heipang, Barkin Ladi Local Government Area of Plateau State, Nigeria. It is located at an altitude of $1200 \mathrm{~m}$ above sea level between longitude $8^{\circ} 53^{\prime} \mathrm{E}$ and $8^{\circ} 54^{\prime} \mathrm{E}$ and between latitude $9^{\circ}$ $39^{\prime} \mathrm{N}$ and latitude $9^{\circ} 40^{\prime} \mathrm{N}$ (Ajaegbu, 1992). The dry season is dominated by the north-easterly tropical continental wind also known as the harmattan between October and April and the wet season is dominated by the 
south-westerly moist tropical maritime wind between May and September (Ajaegbu, 1992). The natural vegetation of Heipang village is close to Guinea Savannah. The vegetation is characterised by shrubs and grass with few scattered trees planted by the people in the village. The average monthly wind speed of the village is about $5 \mathrm{~m} / \mathrm{s}$ as obtained from Meteorological Department, Jos Aiport, Heipang, Plateau State, Nigeria. This shows that Ban village has high wind energy potential for water pumping since the minimum wind speed of 2.5 $\mathrm{m} / \mathrm{s}$ is enough for siting wind pump (Manwell, 2004). This paper is on the design of wind pump system to pump underground water (from borehole) to an overhead tank to supply to Ban village.

\subsection{MATERIALS AND METHODS}

The wind pump system at a tower height of $10 \mathrm{~m}$ and a borehole depth of $27 \mathrm{~m}$ is designed based on the wind speed characteristic as shown in table 1 and the water requirement of Ban village.

Table1. Ten year monthly average wind speed of Jos Airport, Plateau State, Nigeria

\begin{tabular}{|l|l|l|l|l|l|l|l|l|l|l|l|l|}
\hline Month & Jan & Feb & Mar & Apr & May & Jun & Jul & Aug & Sep & Oct & Nov & Dec \\
\hline $\begin{array}{l}\text { Wind speed at } \\
\text { 10m hub } \\
\text { height }\end{array}$ & 6.00 & 4.92 & 5.30 & 5.46 & 5.45 & 5.20 & 5.01 & 4.71 & 4.20 & 3.89 & 3.90 & 4.02 \\
\hline
\end{tabular}

\subsection{Design Theories}

\subsubsection{Water requirement of Ban village}

The water consumed in a community is determined as given in (Hofkes, 1988):

$$
q_{v}=P_{B} W_{p c}
$$

\subsubsection{Borehole depth and safe yield of underground water of Ban village}

The optimum characteristics of boreholes in Ban village as given in (Longpigrand, 2008 and PRUWASSA, 2009) are:
i. Total depth of bore hole -
$30 \mathrm{~m}$
ii. Pump installation depth - $27 \mathrm{~m}$
iii. Yield of boreholes - $\quad 1.5$ litre/second

\subsubsection{Total head of the wind pump system}

Total head of the system, according to Darcy-Weisbach formula, taking into consideration losses on the delivery and suction side of the pipe, is given in (Douglas et al, 1983) as:

$$
H=\frac{8 Q^{2}}{\pi^{2} D_{d}{ }^{4} g}\left[f \frac{L_{p}}{D_{d}}+K+1\right]
$$

\subsubsection{Hydraulic power requirement}

The hydraulic power needed to lift the water from the source (borehole) to an overhead tank can be calculated as given in (Matthew, 2006):

$$
P_{\text {hyd }}=q_{v} \rho_{w} g H
$$

\subsubsection{Wind power potential}

The wind power potential is given as the specific wind power or the power per unit area. It is given in (van Meel, and Smulders, 1989) as:

$$
P_{\text {wind }}=\frac{1}{2} \rho_{a} V^{3}
$$

\subsubsection{Reference area and size of windmill}

The ratio of the hydraulic power of each month divided by the specific wind power potential for that same month has the dimension of area and is referred to as the reference area. The reference area as given in (van Meel, and Smulders, 1989) is:

$$
R_{a}=\frac{P_{\text {hyd }}}{P_{\text {wind }}}
$$

The size of the windmill depends on the diameter of the rotor. This can be obtained from the reference area as given in (van Meel, and Smulders, 1989):

$$
D_{r}=\sqrt{\frac{4 R_{a}}{\pi}}
$$




\subsubsection{Pump size}

The size of a wind pump depends on the volume of water required to be discharged by the pump and is given in (Matthew, 2006) as:

$$
q_{v}=\eta_{v o l} \frac{\pi D_{p}^{2} N_{r} S}{4}
$$

\subsubsection{Design speed}

The design wind speed is that which the overall efficiency of the system reaches a maximum.

It is also determined by equating the net rotor power to hydraulic power as given in (Lysen, 1983):

$$
V_{d}=\sqrt{\frac{\eta_{v o l} S D_{p}^{2} \lambda_{d} \rho_{w} g H}{4\left(C_{p}\right)_{\max } \eta_{\text {mech }} \rho_{a} \pi R^{3}}}
$$

\subsubsection{Capacity of storage tank}

The capacity of the storage tank can be determined from the product of the daily water requirement and the number of days required for constant water supply as given in (Lancashire et al. 1987):

$$
V_{S}=W_{d} \times S_{F}
$$

\subsection{Wind pump simulation}

Wind Energy Resource Analysis (WERA) software was developed by Prof. Sathyajith Mathew of the Kerala Agricultural University (KAU) and Kelappaji College of Agricultural Engineering and Technology, India (Matthew, 2006). It is used to simulate the performance of the wind pump system at the prospective site. Ban village is about $2 \mathrm{~km}$ away from Jos Airport, thus, a ten year monthly average wind speed data collected from the Airport (see table 1) was used for the simulation as according to literature, when there are no remarkable changes in terrain, wind speed can be applied as far as $25 \mathrm{~km}$ (Stevens and Smulders, 1979).

The overall performance coefficient of a wind rotor coupled to a reciprocating pump can be modeled as in (Burton and Pinilla, 1985) and (Mathew, and Pandey, 2000) which gives us the discharge expected from a wind driven piston pump installed at a given site, over a period T as given in (Matthew, 2006):

$Q_{I P}=2 T C_{p d} \eta_{T P}\left[\frac{\rho_{a} A_{T} V_{o}^{3}}{\rho_{W} g H}\right]\left[1-k_{0}\left(\frac{V_{I}}{V_{o}}\right)^{2}\right] k_{0}\left(\frac{V_{I}}{V_{o}}\right)^{2}\left[\left\{\frac{4 V_{m}^{2}}{\pi\left(V_{o}^{2}-V_{I}^{2}\right)}\left(e^{-X_{I}}-e^{-X_{o}}\right)\right\}-\left\{e^{-X_{I}}\right\}\right]$

$$
\begin{aligned}
& X_{I}=\frac{\pi}{4}\left(\frac{V_{I}}{V_{m}}\right)^{2} \\
& X_{o}=\frac{\pi}{4}\left(\frac{V_{o}}{V_{m}}\right)^{2}
\end{aligned}
$$

\subsection{RESULTS}

Table2. Wind pump parameters as obtained from design calculations

\begin{tabular}{|l|l|}
\hline Population & 1,000 \\
\hline Daily water requirement & $25 \mathrm{~m}^{3} /$ day \\
\hline Total head & $35 \mathrm{~m}$ \\
\hline Hydraulic power requirement & $446 \mathrm{~W}$ \\
\hline Diameter of wind mill & $3.6 \mathrm{~m}$ \\
\hline Diameter of reciprocating pump & $150 \mathrm{~mm}$ \\
\hline Stroke of reciprocating pump & $220 \mathrm{~mm}$ \\
\hline Design speed & $7.3 \mathrm{~m} / \mathrm{s}$ \\
\hline Storage tank capacity & $75 \mathrm{~m}^{3}$ \\
\hline
\end{tabular}


Q WERA

FILE EDIT SITE WIND TURBINE WIND PUMP RUN WINDOWS HELP

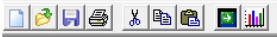

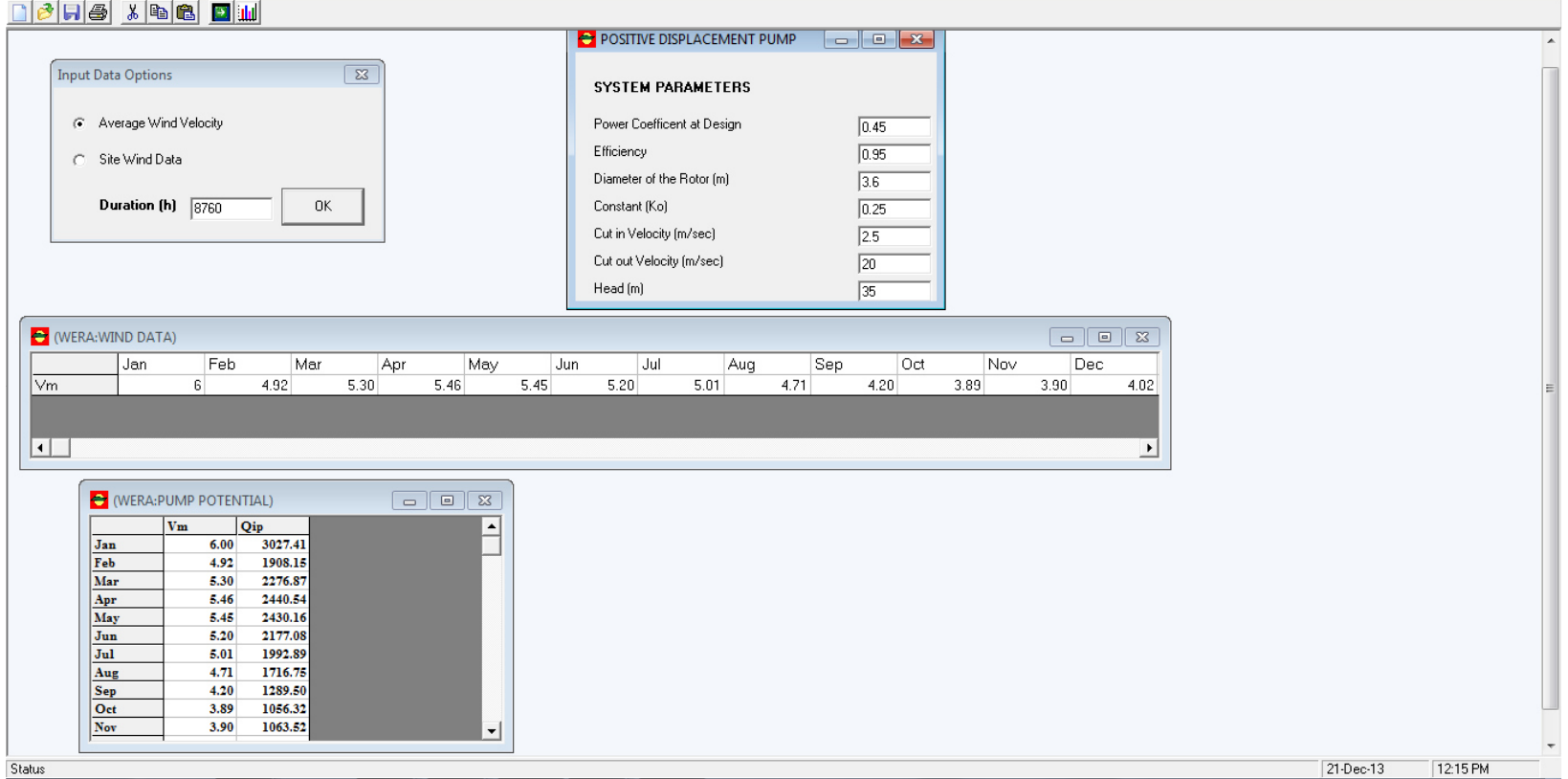

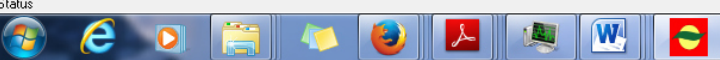

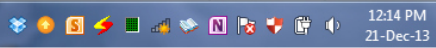

Figure1. Result display of WERA software wind pump simulation

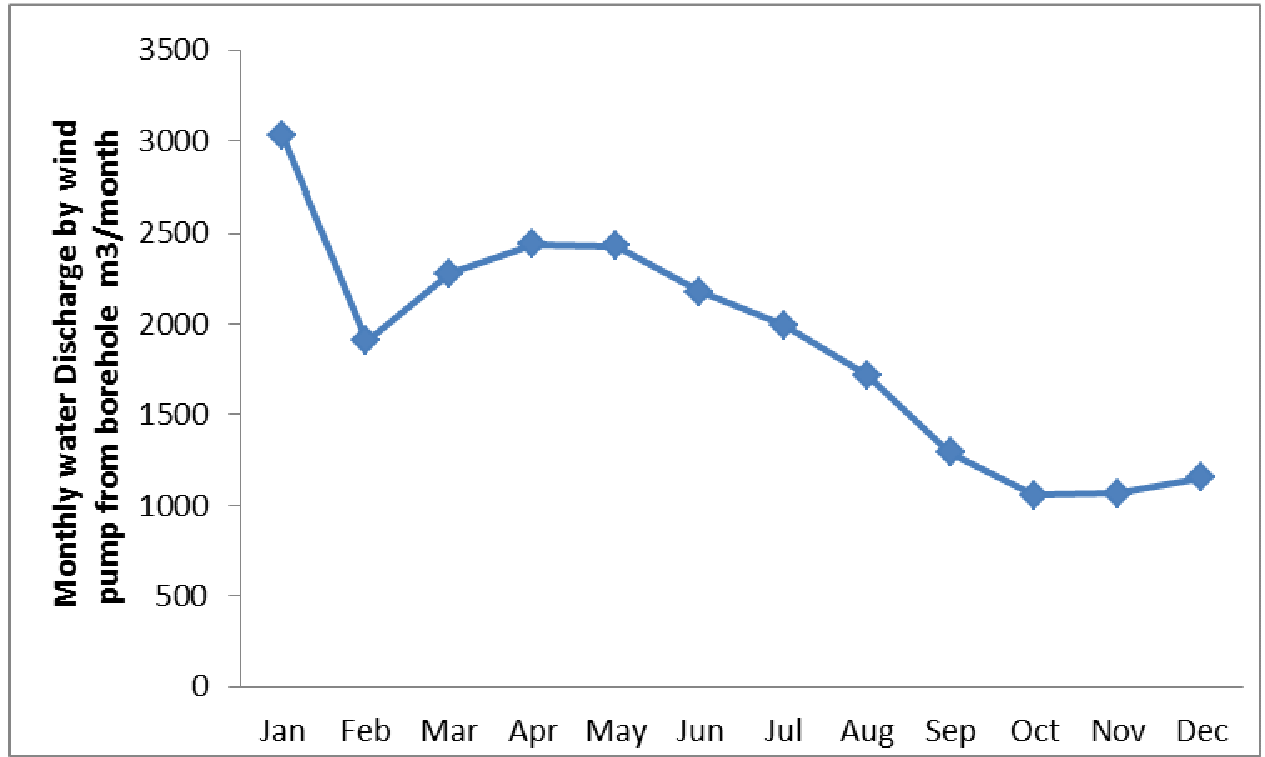

Figure2. Plot of water discharge by wind pump against months of the year as obtain from WERA software simulation 


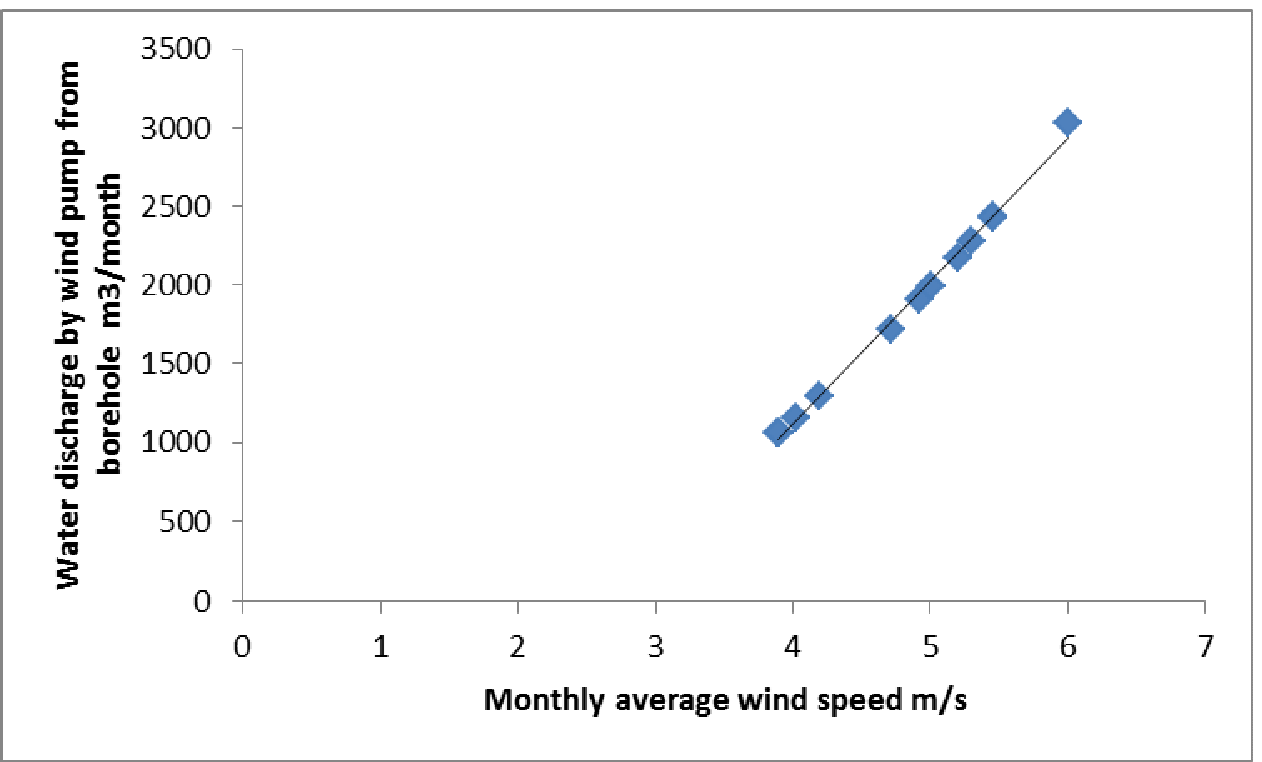

Figure3. Plot of monthly water discharge from borehole by wind pump against Monthly average wind speed as obtained from WERA software simulation

\subsection{DISCUSSION}

Table 2 shows that based on the wind speed and underground water characteristic of Ban village, it would require a wind pump of $3.6 \mathrm{~m}$ diameter to supply a daily water requirement of $25 \mathrm{~m}^{3}$ for a population of 1,000 . This implies that three units of such wind pump will adequately meet the water need of Ban village which has a population of 3,000 .

Figure 2 is a plot of the water discharge by wind pump against months of the year as obtain from WERA software simulation. The trend of the curve shows that maximum volume of water discharged from borehole by the wind pump occurs in January which corresponds to the month with the highest monthly average wind speed as shown in table 1. Similarly, the lowest water discharge occurs in October, which is the month with the lowest monthly average wind speed. This implies that the design month for the wind pump is October since it is the month with the lowest wind speed for the year.

In figure 3 indicates a linear relation between the monthly water discharges from borehole by wind pump against monthly average wind speed as obtained from WERA software simulation programme, When the curve is extrapolated, it intersects the horizontal axis at about $2.5 \mathrm{~m} / \mathrm{s}$ which corresponds to the cut-in wind speed for the wind pump. This implies that the wind pump will begin to discharge at wind speed of $2.5 \mathrm{~m} / \mathrm{s}$.

\subsection{CONCLUSION}

The wind energy potential of Ban village is high enough to pump water from borehole to an overhead tank. The water consumption of Ban village is high and cannot be adequately supplied by hand pump. Hence, some other sophisticated means like using wind pump would have to be employed.

For adequate water supply three units of $3.6 \mathrm{~m}$ diameter wind pump would be required for Ban village with the population of 3,000 .

\section{REFERENCE}

Ajaegbu, H. I. (1992). Jos Plateau Environmental Resources Development, (Jos University, Press, Jos, Nigeria). Argaw, N., Foster, R. and Ellis, A. (2001). Renewable Energy for Water Pumping Applications in Rural Villages Period of Performance: NREL, New Mexico State University.

Burton, J. D., and Pinilla, A. E. (1985) Water pump for wind mills - A comparison between two commercially available systems from South America. Wind Eng. 9 (1): 50-58

Douglas, J.F., Gasiorek, J.M. and J.A. Swaffield, J.A. (1983). Fluid Mechanics (London: Pitman, 1983)

Fraenkel, P. (1986). Water Pumping Devices: A Handbook for Users and Choosers. Prepared by UNFAO, IT Publications Ltd, UK.

Guyton, A.C. (1991). Text book of Medical Physiology (8th ed) Philadelphia: W.B.Sunder

Hofkes, E. (1988).Small Community Water Supply. John Wiley and Sons, New York

Lancashire, S., Kenna, J. and P. Fraenkel, P. (1987). Wind pumping Handbook (London: International Technology Publications)

Longpigrand, (2008). Report of a consultant firm on the hydro-geophysical investigation of PW Nigeria Limited 
Base Camp, Ban village, Heipang, Nigeria.

Lysen, E.H (1983). Introduction to wind energy (Amersfoort, Netherlands: CWD-Consulting Services Wind Energy Developing Countries)

Manwell, N. (2004). Hybrid Energy Systems, Encyclopedia of Energy, (Elsevier Inc)

Matthew, S. (2006). Wind Energy, Fundamental, Resource Analysis and Economic, (Springer- Verlag, New York).Meteorological Department, Jos Aiport, Heipang, Plateau State, Nigeria.

PRUWASSA (2009). Geo-hydrological Analysis Report of Ban village, Heipang, Nigeria.

Stevens, M.J., and Smulders, P.T. (1979). Wind Energy Engineering Journal, 2, 3.UNESCO report "The Nigerian Observer" of September 9th, 2011,

van Meel, J. and Smulders, P. (1989) Wind pumping Hand book, World Bank Technical Paper, Industry and Energy Series

\section{NOMENCLATURE}

\begin{tabular}{|c|c|c|}
\hline$A_{T}$ & - & Wind mill area, $m^{2}$ \\
\hline$C_{P d}$ & - & Power coefficient of the rotor at the design point \\
\hline$\left(C_{p}\right)_{\mathrm{ma}}$ & ax - & Maximum power coefficient of the windmill \\
\hline$D_{d}$ & - & Diameter of pipe, $m$ \\
\hline$D_{p}$ & - & Diameter of the pump $m$ \\
\hline$D_{r}$ & - & Rotor diameter, $m$ \\
\hline$f$ & - & Friction factor, determined from the Moody chart \\
\hline$g$ & - & Acceleration due to gravity, $m / s^{2}$ \\
\hline$k_{0}$ & - & Starting behavior of the rotor pump combination constant \\
\hline$K$ & - & Loss coefficient of the pipe \\
\hline$L_{p}$ & - & Length of pipe, $m$ \\
\hline$H$ & - & $\begin{array}{l}\text { Total head (including Static and dynamic head and head losses in suction } \\
\text { and delivery pipes due to friction), } m\end{array}$ \\
\hline$P_{B}$ & - & Population of the community \\
\hline$P_{\text {hyd }}$ & - & Hydraulic power, W \\
\hline$P_{\text {wind }}$ & - & Wind power potential, $W$ \\
\hline$q_{v}$ & - & Water consumed by community, $\mathrm{m}^{3} / \mathrm{s}$ \\
\hline$Q$ & - & Volume flow rate, $m^{3} / s$ \\
\hline$R$ & - & Radius of wind mill, $m$ \\
\hline$R_{a}$ & - & Reference area, $m^{2}$ \\
\hline$S$ & - & Stroke of the pump, $m$ \\
\hline$S_{F}$ & - & Days for constant water supply, \\
\hline$T$ & - & Time in hours over which the wind pump runs \\
\hline$V$ & - & Wind speed, $m / s$ \\
\hline$V_{S}$ & - & Storage tank capacity, $m^{3}$ \\
\hline$V_{d}$ & - & Design speed, $\mathrm{m} / \mathrm{s}$ \\
\hline$V_{o}$ & - & Cut-out speed, $m / s$ \\
\hline$V_{I}$ & - & Cut-in speed, $m / s$ \\
\hline$V_{m}$ & - & Wind mean speed, $m / s$ \\
\hline$W_{p c}$ & - & Per capita water consumption, $\mathrm{m}^{3} / \mathrm{s}$ \\
\hline
\end{tabular}


$W_{d} \quad$ - Daily water consumption, $m^{3} /$ day

$\rho_{a} \quad$ - Density of air, $\mathrm{kg} / \mathrm{m}^{3}$

$\rho_{w} \quad$ - $\quad$ Density of water, $\mathrm{kg} / \mathrm{m}^{3}$

$\eta_{v o l} \quad$ - $\quad$ Volumetric efficiency of the pump

$\eta_{\text {mech }} \quad$ - Mechanical efficiency 
The IISTE is a pioneer in the Open-Access hosting service and academic event management. The aim of the firm is Accelerating Global Knowledge Sharing.

More information about the firm can be found on the homepage:

http://www.iiste.org

\section{CALL FOR JOURNAL PAPERS}

There are more than 30 peer-reviewed academic journals hosted under the hosting platform.

Prospective authors of journals can find the submission instruction on the following page: http://www.iiste.org/journals/ All the journals articles are available online to the readers all over the world without financial, legal, or technical barriers other than those inseparable from gaining access to the internet itself. Paper version of the journals is also available upon request of readers and authors.

\section{MORE RESOURCES}

Book publication information: http://www.iiste.org/book/

Academic conference: http://www.iiste.org/conference/upcoming-conferences-call-for-paper/

\section{IISTE Knowledge Sharing Partners}

EBSCO, Index Copernicus, Ulrich's Periodicals Directory, JournalTOCS, PKP Open Archives Harvester, Bielefeld Academic Search Engine, Elektronische Zeitschriftenbibliothek EZB, Open J-Gate, OCLC WorldCat, Universe Digtial Library, NewJour, Google Scholar

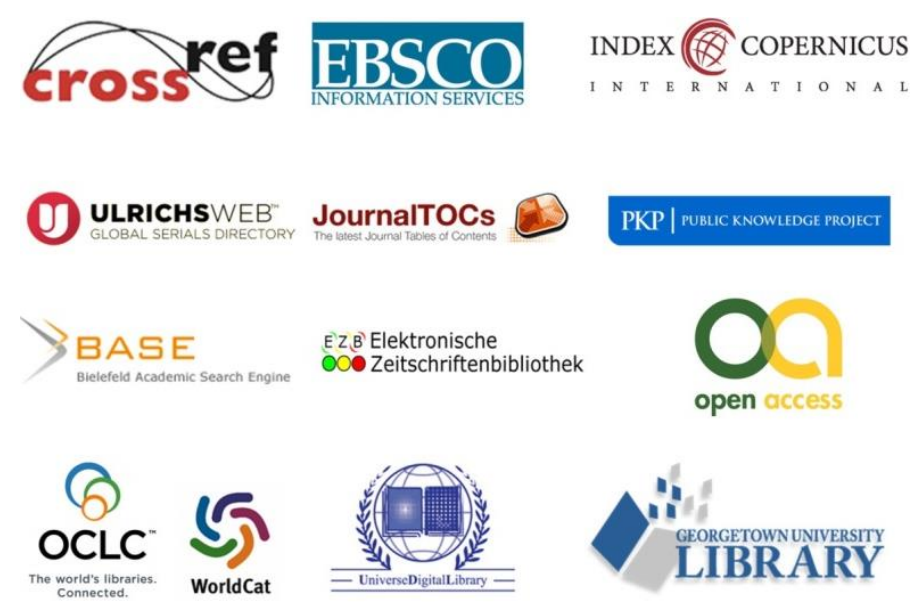

